\title{
Prevention of complications of pregnancy and childbirth of patients with a burdensome gynecological anamnesis
}

\author{
T.P. Andriichuk \\ Kyiv Medical University
}

The objective: determination of the effectiveness of prevention and medicinal correction of placental dysfunction in pregnant women with chronic salpingo-oophoritis.

Materials and methods. The study included 100 pregnant women (basic group) with chronic salpingo-oophoritis, of these, I group (50 women) included patients who received proposed treatment and prevention approach, II group (50 women) received a common set of treatment and prevention measures. The proposed treatment-and-prophylactic approach included prophylactic administration to pregnant women with chronic salpingo-oophoritis from the 8th to the 10th and from the 16th to the 18th week inclusive of natural micronized progesterone at a dose of 100 mg intravaginally twice a day for two weeks. Venotonik and angioprotector were prescribed prophylactically at dose $600 \mathrm{mg}$ from 18 weeks to 37-38 weeks of pregnancy. For therapeutic purposes (blood flow disorders in the uterine arteries and vessels of the umbilical cord that are determined by Doppler), the drug was prescribed at dose $600 \mathrm{mg}$ twice a day for 3-4 weeks.

Results. A lower frequency of obstetric and perinatal complications was found in the women in I group than in the patients in the II group. Thus, the rate of placental dysfunction was $6.0 \pm 3.36 \%$ vs. $34.0 \pm 6.7 \%$, respectively, oligohydramnios $6.0 \pm 3.36 \%$ and $12.0 \pm 4.59 \%$, polyhydramnios $-10.0 \pm 4.24 \%$ and $22.0 \pm 5.86 \%$, fetal distress during childbirth $-6.0 \pm 3.36 \%$ and $14.0 \pm 4.91 \%$, cesarean section $-12.0 \pm 4.6 \%$ and $24.0 \pm 4.27 \%$.

In the group of patients with treatment-and-prophylactic approach, the mean of the body weight of newborns was $3486.7 \pm 312.71 \mathrm{~g}$, and in women who received a common set of treatment-and-prophylactic measures $-3099.8 \pm 295.69 \mathrm{~g}$. The mean of the assessment of the condition of newborns by the Apgar scale at the 1 st minute $-7.92 \pm 1.54$ and $6.81 \pm 1.16$ points, respectively.

Conclusions. The use of micronized natural progesterone and the drug diosmin $600 \mathrm{mg}$ in pregnant women with a history of chronic salpingo-oophoritis reduces the rate of obstetric and perinatal complications during pregnancy.

Keywords: pregnancy, chronic salpingo-oophoritis, placental dysfunction, prevention, treatment.

\section{Профілактика ускладнень вагітності та пологів у пацієнток із обтяженим гінекологічним анамнезом Т.П. Андрійчук}

Мета дослідження: визначення ефективності профілактики та медикаментозної корекції плацентарної дисфункції у вагітних із хронічним сальпінгоофоритом.

Матеріали та методи. У дослідження увійшли 100 вагітних (основна група) із хронічним сальпінгоофоритом. 3 них до I групи (50 жінок) включені пацієнтки, які отримували запропонований нами лікувально-профілактичний підхід, до II групи - 50 жінок, які отримували загальноприйнятий комплекс лікувально-профілактичних заходів. Запропонований нами лікувально-профілактичний підхід передбачав профілактичне призначення вагітним із хронічним сальпінгоофоритом з 8-го до 10-го і з 16-го до 18-го тижня включно препарату натурального мікронізованого прогестерону у дозі 100 мг інтравагінально двічі на добу протягом двох тижнів. Венотонік і ангіопротектор призначали профілактично по 600 мг з 18-го тижня до 37-38 тиж вагітності. 3 лікувальною метою (допплерометрично визначаються порушення кровообігу у маткових артеріях і судинах пуповини) препарат призначали по 600 мг двічі на добу протягом 3-4 тиж.

Результати. У жінок I групи встановлено більш нижчу частоту акушерських та перинатальних ускладнень щодо

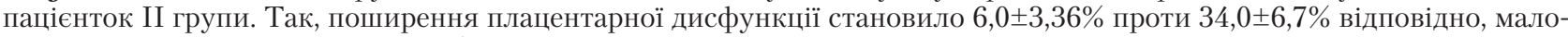
воддя $-6,0 \pm 3,36 \%$ та $12,0 \pm 4,59 \%$, багатоводдя - 10,0 $44,24 \%$ та $22,0 \pm 5,86 \%$, дистресу плода під час пологів - $6,0 \pm 3,36 \%$ та $14,0 \pm 4,91 \%$, кесарева розтину $-12,0 \pm 4,6 \%$ та $24,0 \pm 4,27 \%$.

У групі пацієнток, яким запропоновано лікувально-профілактичний підхід, маса тіла при народженні дитини становила $3486,7 \pm 312,71$ г, а у жінок, які отримували загальноприйнятий комплекс лікувально-профілактичних заходів, -

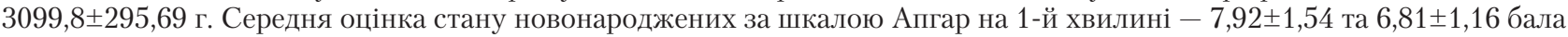
відповідно.

Заключення. Застосування мікронізованого натурального прогестерону та препарату діосмін 600 мг у вагітних із хронічним сальпінгоофоритом в анамнезі сприяє зниженню частоти акушерських та перинатальних ускладнень вагітності.

Ключові слова: вагітність, хронічний сальпінгоофорит, плащентарна дисфункція, профілактика, лікування. 


\section{A K У Ш E P C T B O}

\section{Профилактика осложнений беременности и родов у пациенток с отягощенным гинекологическим анамнезом Т.П. Андрейчук}

Цель исследования: определение эффективности профилактики и медикаментозной коррекции плацентарной дисфункции у беременных с хроническим сальпингоофоритом.

Материалы и методы. В исследование вошли 100 беременных (основная группа) с хроническим сальпингоофоритом. Из них в I группу (50 женщин) включены пациентки, которые получали предложенный нами лечебно-профилактический подход, во II группу - 50 женщин, получавших общепринятый комплекс лечебно-профилактических мероприятий.

Предложенный нами лечебно-профилактический подход предусматривал профилактическое назначение беременным с хроническим сальпингоофоритом с 8-й по 10-ю и с 16-й по 18-ю недели включительно препарата натурального микронизированного прогестерона в дозе 100 мг интравагинально дважды в сутки в течение двух недель. Венотоник и ангиопротектор назначали профилактически по 600 мг с 18-й недели до 37-38 нед беременности. С лечебной целью (допплерометрически определяются нарушения кровообращения в маточных артериях и сосудах пуповины) препарат назначали по 600 мг дважды в сутки в течение 3-4 нед.

Pезультаты. У женщин I группы установлено более низкую частоту акушерских и перинатальных осложнений от-

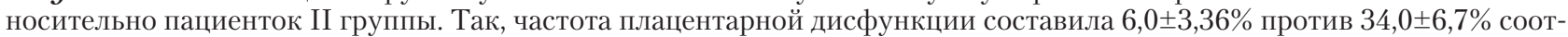

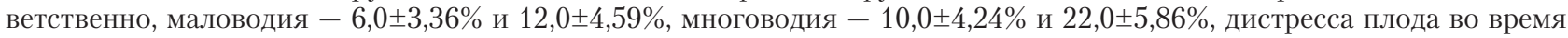
родов $-6,0 \pm 3,36 \%$ и $14,0 \pm 4,91 \%$, кесарева сечения $-12,0 \pm 4,6 \%$ и $24,0 \pm 4,27 \%$.

В группе пациенток, которым предлагался лечебно-профилактический подход, масса тела при рождении ребенка

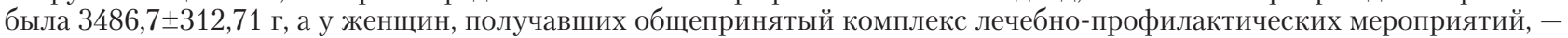

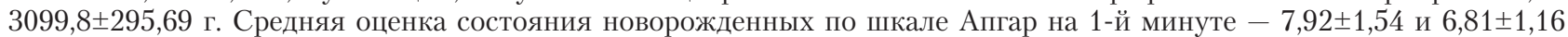
балла соответственно.

Заключение. Применение микронизированного натурального прогестерона и препарата диосмин 600 мг у беременных с хроническим сальпингоофоритом в анамнезе способствует снижению частоты акушерских и перинатальных осложнений беременности.

Ключевые слова: беременность, хронический сальпингоофорит, плачентарная дисфункция, профилактика, лечение.

$\mathrm{T}$ imely, pathogenetically substantiated drug correction of disorders that most often occur in pregnant women with chronic salpingo-oophoritis should be aimed primarily at preventing placental dysfunction (PD) [1,2]. The leading factor that determines the formation (first and second wave of trophoblast invasion) and the functioning of the mother-placenta-fetus system is hormonal supply [3,4]. Data from the scientific literature and the results of our own research indicate that pregnancy in patients with chronic salpingo-oophoritis develops primarily on the background of progesterone deficiency. That is why natural micronized progesterone should be a pathogenetically justified prophylactic and therapeutic agent $[5,6,7]$. The unique mechanism of action, a wide range of therapeutic and prophylactic effects of this drug, the possibility and safety of its use during pregnancy have been proven by many researchers.

According to our research and scientific literature, chronic adnexitis leads to suppression of blood circulation in the uterine and ovarian arteries, disruption of endogenous progesterone production by the corpus luteum and disrupts angiogenesis and trophoblast invasion into the subendometrial vessels of the uterus $[8,9,10]$. This confirms the need for additional administration of exogenous progesterone and necessitates the use of vascular drugs. This drug can be diosmin $600 \mathrm{mg}$, which combines the properties of systemic venotonic and angioprotective. The drug reduces venous congestion by increasing venous tone and reducing their stretching (increases the tropism of norepinephrine to venous myocytes), improves microcirculation (increases capillary resistance and reduces their permeability), restores tissue trophism, improves lymphatic drainage, has anti-inflammatory effect. Diosmin $600 \mathrm{mg}$ increases the content of alpha-actin (contractile protein) in venous myo- cytes, prevents the process of degeneration of the venous wall. The use of diosmin $600 \mathrm{mg}$ provides elimination of disorders of uteroplacental hemodynamics, as well as protection of endothelial elements of spiral arterioles [11,12,13]. The anti-inflammatory effect of the drug is due to anticomplementary activity, inhibition of the release of inflammatory mediators (prostaglandins, leukotrienes), reducing the production of inflammatory mediators (leukotrienes) by blocking lipoxygenase [14,15,16].

The objective: study of the results of prevention and drug correction of PD in pregnant women with a history of chronic salpingo-oophoritis.

\section{MATERIALS AND METHODS}

All patients were examined at 3437 weeks of gestation. The main group includes 100 pregnant women with chronic salpingo-oophoritis, the survey data of which are based on the results of a representative examination. Group I (50 women) includes pregnant women with a history of chronic salpingo-oophoritis, who received our proposed complex of prevention and drug correction of PD, and Group II (50 women), who received a common set of treatment and prevention measures. The survey data of healthy pregnant women are presented by the results of the survey of 50 pregnant women in the physiological obstetrics department.

The treatment methods we used were as follows:

- conventional therapy in cases of clinical signs of PD consisted of a protective regime (hospitalization, exclusion of physical, emotional stress and sexual life), sedatives (valerian, persen), antispasmodics and analgesics (viburcol rectally), vitamin therapy. To eliminate progesterone deficiency, progesterone drugs were administered in the form of injections or enterally; 


\section{A K У Ш E P C T B O}

The results of determining SDR, M $\pm m$

\begin{tabular}{|c|c|c|c|c|}
\hline Terms of examination & $\begin{array}{c}\text { Main group } \\
\mathbf{n = 5 0}\end{array}$ & $\begin{array}{c}\text { Group I } \\
\mathbf{n}=\mathbf{5 0}\end{array}$ & $\begin{array}{c}\text { Group II } \\
\mathbf{n = 5 0}\end{array}$ & $\begin{array}{c}\text { Control group } \\
\mathbf{n = 5 0}\end{array}$ \\
\hline Fetal aorta & $6,02 \pm 0,07$ & $5,61 \pm 0,23$ & $5,89 \pm 0,34$ & $5,55 \pm 0,04$ \\
\hline Umbilical cord vessels & $3,11 \pm 0,11^{\star}$ & $2,35 \pm 0,04^{\star}$ & $2,83 \pm 0,12^{\star \star}$ & $2,20 \pm 0,03$ \\
\hline Uterine artery & $2,49 \pm 0,01^{\star}$ & $1,87 \pm 0,25$ & $1,99 \pm 0,17^{\star *}$ & $1,55 \pm 0,03$ \\
\hline
\end{tabular}

Note: ${ }^{*}-p<0.05$ between indicators in the main and control groups; ${ }^{* \star}-p<0.05$ between indicators in the II and control groups;

${ }^{\Delta}-\mathrm{p}<0.05$ between indicators in the I-th and II-th groups

- micronized progesterone at a dose of $100 \mathrm{mg}$ intravaginally twice a day for two weeks. In cases of diagnosed progesterone deficiency (hormonal studies) or clinical manifestations of PD (threat of miscarriage, threat of premature birth, etc.), natural micronized progesterone is prescribed at a dose of $200 \mathrm{mg}$ twice a day for 2 to 4 weeks from the 8th to the 34th week of pregnancy. Venotonic and angioprotector are prescribed prophylactically at $600 \mathrm{mg}$ from 18 weeks to 37-38 weeks of pregnancy. For therapeutic purposes (dopplerometrically determined circulatory disorders in the uterine arteries and vessels of the umbilical cord), the drug is prescribed $600 \mathrm{mg}$ twice a day for 3-4 weeks.

The effectiveness of both methods was evaluated by clinical, laboratory and hardware research methods compared with the corresponding indicators in healthy pregnant women.

The obtained results were processed by the methods of variation statistics: absolute values - using Student's criterion (t), relative values (\%) - non-parametric Angular transformation criterion (f). The level of probability of error-free prediction was limited by the t-test, respectively $\mathrm{t} \geq 2$ and $\mathrm{P} \geq 95 \%$ or to assess the probability characteristics of the results of any of the statistical methods used $0.001<\mathrm{p}<0.05$. Data processing was performed on a personal computer, some of the statistical methods are programmed by the author. Standard statistical methods of Windows programs were used for multidimensional analysis.

\section{RESULTS AND DISCUSSION}

The results of the analysis of cardiotocography (CTG) indicators testified to the advantages of our proposed approach to the prevention of PD in pregnant women with chronic salpingo-oophoritis. This can be stated on the basis of a significant $(\mathrm{p}<0.05)$ improvement in the frequency of oscillations in Group I (6.7 \pm 0.7$)$, compared with Group II (3.9 \pm 0.6$)$. Other CTG values in group I were also closer to those in healthy pregnant women. A characteristic feature of fetal CTG in mothers with chronic salpingo-oophoritis who received conventional therapy is the presence of decelerations, which are significantly $(\mathrm{p}<0.05)$ more often found in Group II of the examined women.

The total score of CTG in fetuses on the Fisher scale also mostly improved after the proposed therapy and was $8.2 \pm 0.72$ points, which did not differ significantly from the control group ( $8.9 \pm 0.22$ points). After conventional therapy, the score on the Fisher scale was significantly zero (7.5 \pm 0.51$)$, compared with the control.

The score in the main group $-7.2 \pm 0.24$ points, which is significant $(\mathrm{p}<0.05)$ lower than in the control, which indicates the intensity of compensatory reactions of the fetus and the development of its distress.

The results of the study of the biophysical profile of the fetus progesterone and diosmin $600 \mathrm{mg}$. $86.0 \%$ of women in group I and $66.0 \%$ in group II received a score of $10-12$ points, $8-9$ points $-14.0 \%$ and $26.0 \%$, respectively. In the group with conventional therapy, $8.0 \%$ of pregnant women had a score of 6-7 points.

All components of the A.Vintzileos scale in group I approached the corresponding level of indicators in the control group. In the group of patients who were observed using conventional approaches, the scale (heart rate after non-stress test, amniotic fluid volume, placental maturity) was significantly lower $(\mathrm{p}<0.05)$, compared with the corresponding indicators in the control group of patients.

The results of determining the spectra of systolic-diastolic ratio (SDR), in the fetal aorta, umbilical vessels and uterine artery are shown in table 1.

The analysis of the data presented in the table testifies to the advantages of our proposed approach to the prevention of PD in pregnant women with chronic salpingo-oophoritis. This is evidenced by the indicators of SDR in Group I, which are as close as possible to the corresponding indicators in the Control group, and SDR in the vessels of the umbilical cord in this group is significantly lower than in the Group II.

Complicated pregnancy was registered in $96.0 \%$ of patients in the Main group and $38.0 \%$ of women in the Control group.

Characterizing the structure of pregnancy complications after the proposed and generally accepted approach to pregnancy management in patients with chronic salpingo-oophoritis, it should be noted that the incidence of pregnancy complications in women of group I who received the proposed measures was much lower, which could be compared with control. In patients who used the conventional approach, the frequency of pregnancy complications was almost the same as in the Main group.

Characteristics of changes in the placental complex of the examined patients are shown in table 2 .

The analysis of the data given in the table convincingly proves the positive effect of our proposed measures on the state of the fetoplacental complex and a significant reduction in degenerative changes. Prophylactic administration of micronized natural progesterone and metabolic drug in pregnant women with chronic salpingo-oophoritis has led to a significant reduction in the frequency of negative changes in the fetoplacental complex. 


\section{A K У Ш E P C T B O}

Changes in the placental complex in the examined patients, $\mathrm{P} \pm \mathrm{m}$

\begin{tabular}{|c|c|c|c|}
\hline Changes in the placental complex & $\begin{array}{c}\text { Group I } \\
n=50\end{array}$ & $\begin{array}{c}\text { Group II } \\
n=50\end{array}$ & $\begin{array}{c}\text { Control group } \\
n=50\end{array}$ \\
\hline Placental dysfunction & $6,0 \pm 3,36^{*}$ & $34,0 \pm 6,7^{\Delta}$ & $8,0 \pm 3,38$ \\
\hline $\begin{array}{c}\text { Changes in the placenta: } \\
\text { - hyperplasia } \\
\text { - hypoplasia } \\
\text { - calcification }\end{array}$ & $\begin{array}{c}8,0 \pm 3,84 \\
4,0 \pm 2,77 \\
14,0 \pm 4,91\end{array}$ & $\begin{array}{r}18,0 \pm 5,43 \\
14,0 \pm 4,91^{\Delta} \\
28,0 \pm 6,35^{\Delta}\end{array}$ & $\begin{array}{c}6,0 \pm 3,36 \\
2,0 \pm 1,98 \\
8,0 \pm 3,8\end{array}$ \\
\hline Low water & $6,0 \pm 3,36$ & $12,0 \pm 4,59^{\Delta}$ & $2,0 \pm 1,98$ \\
\hline Polyhydramnion & $10,0 \pm 4,24$ & $22,0 \pm 5,86$ & $6,0 \pm 3,36$ \\
\hline Premature detachment of the normally located placenta & $2,0 \pm 1,98$ & $6,0 \pm 3,36$ & - \\
\hline $\begin{array}{l}\text { Fetal growth retardation syndrome: } \\
\qquad \begin{array}{l}- \text { I degree } \\
- \text { II degree }\end{array}\end{array}$ & $\begin{array}{l}6,0 \pm 3,36 \\
2,0 \pm 1,98\end{array}$ & $\begin{array}{l}10,0 \pm 3,0 \\
6,0 \pm 3,36\end{array}$ & $\begin{array}{c}4,0 \pm 2,77 \\
-\end{array}$ \\
\hline
\end{tabular}

Note: ${ }^{*}-p<0.05$ between the indicators in the I and II groups; ${ }^{* *}-p<0.05$ between the indicators in the first and control groups; ${ }^{\Delta}-p<0.05$ between the indicators in the II and control groups.

Complications of childbirth, $(\mathrm{P} \pm \mathrm{m})$

\begin{tabular}{|c|c|c|c|}
\hline Complications of childbirth & $\begin{array}{c}\text { Group I } \\
n=50\end{array}$ & $\underset{n=50}{\text { Group II }}$ & $\begin{array}{c}\text { Control group } \\
\mathbf{n}=\mathbf{5 0}\end{array}$ \\
\hline Premature birth & $6,0 \pm 3,36^{* *}$ & $8,0 \pm 3,84$ & $4,0 \pm 2,77$ \\
\hline Premature rupture of membranes & $12,0 \pm 4,6$ & $16,0 \pm 5,18$ & $10,0 \pm 4,24$ \\
\hline $\begin{array}{c}\text { Anomalies of labor: } \\
\text { - pathological preliminary period } \\
\text { - primary weakness } \\
\text { - secondary weakness } \\
\text { - discoordination }\end{array}$ & $\begin{array}{l}16,0 \pm 5,18 \\
8,0 \pm 3,84 \\
6,0 \pm 3,36 \\
4,0 \pm 2,77\end{array}$ & $\begin{array}{c}15,0 \pm 6,48^{\Delta} \\
12,0 \pm 4,6 \\
12,0 \pm 4,6 \\
6,0 \pm 3,36\end{array}$ & $\begin{array}{c}12,0 \pm 4,6 \\
6,0 \pm 3,36 \\
4,0 \pm 2,77 \\
-\end{array}$ \\
\hline Fetal distress & $6,0 \pm 3,36$ & $14,0 \pm 4,91$ & $4,0 \pm 2,77$ \\
\hline Premature placental abruption (during childbirth) & $2,0 \pm 1,98$ & $2,0 \pm 1,98$ & - \\
\hline $\begin{array}{c}\text { Pathology of placental abruption: } \\
\text { - placental defect } \\
\text { - tight attachment }\end{array}$ & $\begin{array}{l}8,0 \pm 3,84 \\
6,0 \pm 3,36\end{array}$ & $\begin{array}{c}14,0 \pm 4,91 \\
6,0 \pm 3,36\end{array}$ & $\begin{array}{l}6,0 \pm 3,36 \\
2,0 \pm 1,98\end{array}$ \\
\hline $\begin{array}{l}\text { Operative delivery: } \\
\text { - cesarean section } \\
\text { - vacuum extraction } \\
\text { - forceps }\end{array}$ & $\begin{array}{c}12,0 \pm 4,6 \\
6,0 \pm 3,36 \\
-\end{array}$ & $\begin{array}{c}24,0 \pm 4,27^{\Delta} \\
12,0 \pm 4,6 \\
2,0 \pm 1,98\end{array}$ & $\begin{array}{c}6,0 \pm 3,36 \\
4,0 \pm 2,77 \\
-\end{array}$ \\
\hline $\begin{array}{c}\text { Total blood loss } \\
\text { (>0.5\% of body weight) }\end{array}$ & $4,0 \pm 2,77$ & $10,0 \pm 4,24$ & $4,0 \pm 2,77$ \\
\hline
\end{tabular}

Note: * $-p<0.05$ between indicators in the 1 st and 2 nd groups; ${ }^{*}-p<0,05$ between indicators in the Group I and Control groups; ${ }^{\Delta}-p<0.05$ between the indicators in the Group II and Control groups.

The main complications of childbirth in our examined patients after the application of treatment and prevention measures are shown in table 3.

The analysis of the data given in the table shows that in pregnant women who received our proposed treatment and prevention complex, the frequency of complications of childbirth was significantly reduced compared to patients who followed the generally accepted approaches. Thus, the frequency of pathological preliminary period, secondary weakness of labor, fetal distress, the frequency of cesarean section and vacuum extraction of the fetus and the frequency of pathological blood loss decreased by 2 times or more.
The obtained data on the average score of newborns on the Apgar scale in the examined patients are given in table 4.

The better condition of newborns in women who received the proposed complex indicates its benefits. The score on the Apgar scale at the first and fifth minutes was 1 point higher in these children compared with newborns from mothers who received a conventional treatment and prevention complex for the prevention of PD.

There is an increase in the average weight of newborns in women of the Group I (3486.7 \pm 312.71$)$, compared with the Group II $-3099.8 \pm 295.69$ (almost $400 \mathrm{~g}$ ). This further indicates the benefits of the proposed measures and the development of fruits in more favorable conditions. 
A K У Ш E P C T B O

Table 4

The average score on the score of newborns on the Apgar scale in the examined groups, $M \pm m$

\begin{tabular}{|c|c|c|}
\hline Surveyed groups & In the 1st minute, points & In the 5st minute, points \\
\hline Pregnant women with chronic salpingo-oophoritis, $\mathrm{n}=100$ & $6,34 \pm 0,14^{*}$ & $7,58 \pm 0,1^{*}$ \\
\hline Group I, $\mathrm{n}=50$ & $7,92 \pm 1,54$ & $8,36 \pm 1,44$ \\
\hline Group II, $\mathrm{n}=50$ & $6,81 \pm 1,16$ & $7,23 \pm 1,64$ \\
\hline Control group, $\mathrm{n}=50$ & $8,36 \pm 0,09$ & $8,92 \pm 0,12$ \\
\hline
\end{tabular}

Note. ${ }^{*}-p<0,05$ between indicators in the Main and Control group.

\section{CONCLUSION}

Our analysis of the peculiarities of pregnancy, childbirth, fetal status and newborns in women with chronic salpingo-oophoritis, who followed the proposed and generally accepted approach to pregnancy, indicates significant benefits of inclusion in the complex of natural micronized progesterone and metabolic drugs. A significant reduction in complications of pregnancy and childbirth, higher weight and Apgar score indicate the normal functioning of the fetoplacental complex in patients who adhered to the proposed treatment and prevention complex.

Thus, the use of micronized natural progesterone and the drug diosmin $600 \mathrm{mg}$ in the treatment of pregnant women with chronic salpingo-oophoritis can significantly reduce the incidence of complications during pregnancy and childbirth, as well as improve the condition of newborns.

The direction of further research, in our opinion, may be to improve the treatment of chronic adnexitis during the preparation of women for pregnancy. Qualitative therapy of chronic salpingo-oophoritis will promote the normal course of adaptive mechanisms of women in early pregnancy, the physiological course of the first and second wave of syncytiotrophoblast invasion and prevention of $\mathrm{PD}$ in patients with chronic salpingo-oophoritis.

\section{Information about the author}

Andriichuk Tetyana Petrivna - Department of Obstetrics and Gynecology, Kyiv Medical University, Academy of Human Health, 02091, Kyiv, Kharkivske Shosse, 121; теl.: (044) 564-21-65; (050) 352-46-69.E-mail:0503524669@ukr.net

\section{Відомості про автора}

Андрійчук Тетяна Петрівна - Кафедра акушерства і гінекології ПВНЗ «Київський медичний університет», КНП «Академія здоров'я людини», 02091, м. Київ, Харківське шосе, 121; тел.: (044) 564-21-65; (050) 352-46-69. E-mail:0503524669@ukr.net

\section{Сведения об авторе}

Андрейчук Татьяна Петровна - Кафедра акушерства и гинекологии ПВНЗ «Киевский медицинский университет», КНП «Академия здоровья человека», 02091, г. Киев, Харьковское шоссе, 121; тел.: (044) 564-21-65; (050) 352-46-69. E-mail:0503524669@ukr.net

\section{REFERENCES}

1. Berbets AM, Andriets OA, Nitsovich IR. Formation of hormonal function of the fetoplacental complex in women with the threat of miscarriage in early gestation. Current issues of pediatrics, obstetrics and gynecology. 2013. 1:193-5.

2. Romanenko TG. Placental dysfunction: diagnosis, treatment, prevention. Women's health. 2010;10(56):28-30.

3. Grishchenko OV, Storchak $A B$, Zinevich EM. Possibilities of correction of hemodynamic disorders in preeclampsia by restoring the functional activity of the endothelium. Women's Health. 2011; 5(61):28-36.

4. Borovkova El. Interaction of infectious agents with the body of a pregnant woman as a risk factor for intrauterine infection of the fetus. Women's Health. 2013;2(78):95-9.
5. Senchuk AYa, Hinzburh VH, Chermak II at al. Emergencies in obstetric practice: a practical guide. Kyiv: Fenix; 2019.336 p.

6. Nazarenko LG, Nikifor LV. Progesterone and the risk of late complications of pregnancy. Women's health. 2015;8(104):106-9. Early pregnancy. From pre-pregnancy preparation to healthy gestation. 3rd ed. M.: StatusPresens; 2018. 800 p.

8. Senchuk AYa. The effectiveness of complex anti-inflammatory drugs in the empirical therapy of acute salpingooophoritis. Current issues of pediatrics, obstetrics and gynecology. 2013;2(12): 113-6.

9. Radzinsky VE. Obstetric aggression. Status Praesens. 2017;2:872.

10. Shcherbina NA, Lazurenko W, So-
7. Radzinskii VE, Orazmuradov AA et al. rokolat YuV et al. Collection of Science Practices of the Association of Obstetricians and Gynecologists of Ukraine. An integrated approach to the rehabilitation of women who have had inflammatory diseases of the genitals. K.:Polygraph plus; 2013, p.409-11.

11. Vdovichenko YuP, Babkina TN, Volik NK. Dynamics of Doppler indicators of blood flow in the uterine arteries during pregnancy at 11-14 and 19-22 weeks depending on its outcome. Women's Health. 2015;8(104):112-5.

12. Veropotvelyan PN, Veropotvelyan NP, Tsekhmystrenko IS. Collection of scientific works of the Association of Obstetricians and Gynecologists of Ukraine. Factors of anti-infective protection of the fetus. 2016;2(38):95-103.

13. Podolsky W, Podolsky VL et al. Collection of scientific works of the Associa- tion of Obstetricians and Gynecologists of Ukraine. The relationship between the microbiocenosis of urogenital organs and the state of the placenta in pregnant women with the infectious-inflammatory process of the genitals. K.:Polygraph Plus; 2013, p. 315-21.

14. Krotik El. Clinical and statistical analysis of anamnesis of women who have had inflammatory diseases of the reproductive system. Reproductive health. Eastern Europe. 2020;10(3):268-80.

15. Lipatov IS, Tezikov YuV, Lineva OI. Pathogenetic mechanisms of placental insufficiency and preeclampsia. Obstetrics and gynecology. 2017;9:64-76.

16. Makatsariya AD, Chervenaka FA, Bitsadze VO. High-risk pregnancy. M.: Ltd. Publishing House "Medical Information Agency"; 2015.920 p. 